\title{
PERBEDAAN EFEKTIVITAS HAND-SANITIZER DENGAN CUCI TANGAN MENGGUNAKAN SABUN SEBAGAI BENTUK PENCEGAHAN COVID-19
}

\section{Difference in the effectiveness of hand-sanitizer by washing hands using soap as a covid-19 preventive measure}

\author{
Moh. Rivai Nakoe*1, Nur Ayini S lalu, ${ }^{2}$ Yesintha Amelia Mohamad ${ }^{3}$ \\ Fakultas Olahraga dan Kesehatan, Universitas Negeri Gorontalo \\ E-mail : kaka.nakoe@gmail.com
}

\begin{abstract}
Abstrak
Pandemi coronavirus 2019-2020 atau dikenal sebagai pandemi covid-19 adalah peristiwa menyebaranya di seluru dunia. Penyakit disebabkan oleh koronavirus jenis baru yang diberi nama SARS-CoV-2. Tangan adalah salah satu anggota tubuh yang harus di jaga kebersihannya, karena tangan sering terkontaminasi kotoran maupun mikroba sehingga dengan melalui perantara tangan mikroba akan masuk kedalam tubuh. Kebersihan tangan dalam bidang mikrobiologi sangat perlu karena melalui media tangan dapat menimbulkan penyebaran mikroorganisme.Tujuan penelitian ini adalah melaksanakan studi literatur secara sistematis untuk mengetahui perbedaan efektivitas hand sanitizer dengan cuci tangan menggunakan sabun sebagai bentuk pencegahan covid-19.Metode yang digunakan adalah studi literature secara sistematis, yang dimulai dengan menggunakan kata kunci yang berisi jurnal berbahasa Indonesia dan Inggris yang kredibel. Pada Hasil studi menunjukkan bahwa Hand sanitizer yaitu sebuah produk yang dapat membersihkan tangan yang mengandung antiseptik yang bentuknya gel yang apabila digunakan mencuci tangan tidak perlu lagi membilas dengan air.Produk berbasis alkohol, yang mencakup hampir semua produk "disinfektan", mengandung larutan alkohol persentase tinggi (biasanya 60-80\% etanol) dan membunuh virus dengan cara yang sama.Tetapi sabun lebih baik karena hanya membutuhkan sedikit air sabun, yang, dengan menggosok, menutupi seluruh tangan dengan mudah.
\end{abstract}

Katakunci:Covid-19;Hand-sanitizer; Cuci Tangan

\section{Abstrak}

The corona virus pandemic 2019-2020 or known as the covid-19 pandemic is spreading throughout the world. The disease is caused by a new type of coronavirus named SARS-CoV-2. Hand hygiene is very important to maintain because human hands are often contaminated with microbes, so the hands can be an intermediary for microbial entry into the body. Hand hygiene is also very much needed in the field of microbiology and in care or places that are prone to spread of microorganisms through the media of our hands. The purpose of this research is to carry out a systematic literature study to determine the differences in the effectiveness of handsanitizer by washing hands using soap as a form of cov-19 prevention. The method used is a systematic study of literature, which begins by using keywords that contain credible Indonesian and English journals. The study results show that the Handsanitizer is a hand sanitizing product in the form of a gel containing an antiseptic substance that is used to wash hands without rinsing it with water. Its use is more effective at killing resident flora and transient flora than washing hands with antiseptic soap or with ordinary soap and water. Alcohol-based products, which include almost all "disinfectant" products, contain high percentage alcohol solutions (usually 60-80\% ethanol) and kill viruses in the same way.But soap is better because it only requires a small amount of soapy water, which, by rubbing, cover the entire hand easily.

Keywords: Covid-19; Hand Wash; Hand-sanitizer 


\section{PENDAHULUAN}

Pandemi Koronavirus 2019-2020 atau dikenal sebagai pandemi COVID-19 adalah peristiwa menyebaranya di seluru dunia. Penyakit disebabkan oleh koronavirus jenis baru yang diberi nama SARS-CoV-2. Pertama kalinya wabah COVID -19 terdeteksi di Kota Wuhan, Provinsi Hubei, Tiongkok pada bulan Desember tahun 2019, dan oleh WHO (Organisasi Kesehatan Dunia) pada Maret 2020 hingga April 2020, telah dilaporkan lebih dari 2 juta kasus COVID-19 di lebih dari 210 negara dan wilayah yang mengakibatkan ? 195,755 orang meninggal dunia dan yang sembuh ?781,109 orang.

Virus SARS-CoV-2 diperkirakan menyebar di antara orang - orang melalui percikan pernapasan yang dihasilkan pada saat batuk dan percikan dari seseorang yang sedang bersin serta didapat dari permukaan benda yang sudah terkontaminasi yang kemudian secara tidak sengaja menyentuh wajah seseorang.Penyakit COVID-19 sangat menular saat penderitanya mengalami gejala, walaupun mungkin saja penyebarannya terjadi sebelum adanya gejala muncul.Paparan virus dan awalnya gejala biasanya terjadi dalam periode waktu sekitar lima hari, tetapi juga dapat berkisar smpai empat belas hari. Gejala yang terjadi pada umumnya diantaranya, demam, batuk, dan sesak napas.Komplikasi yang terjadi berupa penyakit pernapasan akut berat dan pneumonia, dan untuk saat ini belum ditemukan vaksin atau antivirus khusus untuk menangani penyakit tersebut.Pengobatan secara primer yang dilakukan berupa terapi suportif dan simtomatik. Beberapa langkah pencegahan direkomendasikan yaitu diantaranya menjaga jarak dengan orang lain, mencuci tangan dengan sabun, menutup mulut saat batuk atau menggunakan masker, serta memantau dan mengisolasi diri dari orang yang dicurigai terinfeksi virus ${ }^{1}$.

\section{METODE PENELITIAN}

Metode yang digunakan adalah studi literature secara sistematis, yang dimulai dengan menggunakan kata kunci yang berisi jurnal berbahasa Indonesia dan Inggris yang kredibel.

\section{HASIL DAN PEMBAHASAN}

\subsection{Definisi Mencuci Tangan}

Tangan adalah salah satu anggota tubuh yang harus di jaga kebersihannya, karena tangan sering terkontaminasi kotoran maupun mikroba sehingga dengan melalui perantara tangan mikroba akan masuk kedalam tubuh. ${ }^{3}$ Kebersihan tangan juga sangat perlu dilakukan terutama pada bidang mikrobiologi maupun pada tempat perawatan serta tempat - tempat dimana sering terjadi penyebaran mikroorganisme melalui media tangan kita. ${ }^{4}$ Mencuci tangan merupakan proses yang secara mekanik melepaskan kotoran yang menempel pada tangan dengan memakai deterjen yang mengandung agen antiseptik serta air yang mengalir ${ }^{8}$,dimulai dari ujung jari sampai siku dan lengan dengan cara tertentu sesuai dengan kebutuhan. ${ }^{12}$

Hal- hal yang perlu di ingat saat mencuci tangan $^{8}$ : 1) Bila jelas terlihat atau terkontaminasi oleh bahan yang mengandung protein, tangan harus dicuci dengan memakai deterjen dan air dialirkan. 2) Bila tangan tidak jelas terlihat kotor atau terkontaminasi, harus digunakan antiseptik berbasis alkohol untuk dekontaminasi tangan rutin. 3) Sebelum memulai kegiatan tangan dipastikan dalam keadaan kering.

Indikasi mencuci tangan ${ }^{8}:$ 1) Lakukan segera setelah tiba di tempat kerja. 2) Lakukan sebelum: a) Melakukan kontak secara langsung dengan penderita; b) Melakukan pemeriksaan klinis dan tindakan invasif (pemberian suntikan intra vaskuler) wajib menggunakan alat pelindung diri seperti sarung tangan; c) Mempersiapkan makanan; d) Memberi makan 
pasien; e) Meninggalkan rumah sakit. 3) Lakukan prosedur tertentu terhadap pasien yang sama pada tangan yang terkontaminasi untuk menghindari terjadinya kontaminasi silang. 4) Lakukan setelah: a) Melakukan kontak dengan penderita; b) Melepaskan alat pelindung diri; c) Melepaskan sarung tangan; d) kontak dengan cairan tubuh, darah, ekskresi, sekresi, eksudat luka, dan alat -alat yang diduga terkena cairan tubuh, darah, ekskresi pada saat memakai sarung tangan maupun tidak; e) Memakai toilet umum, serta sebelum tangan menyentuh hidung. Oleh karena itu mencuci tangan dianjurkan adalah dengan memakai sabun dengan mencuci jari jemari dengan air mengalir agar menjadi bersih dan memutuskan penyebaran kuman. ${ }^{18}$

Membersihkan tangan dengan air dan sabun tingkat keampuhan menghilangkan bakteri ditangan dapat berbeda, dalam hal ini jika hanya di cuci dengan air, bakteri yang akan keluar hanya sedikit, sedangkan sabun dapat mengeluarkan banyak bakteri karena dalam sabun terdapat bahan khusus yang dapat mengendalikan bakteri yang ada pada tangan, dalam hal ini terdapat beberapa bahan aktif yang terkandung dalam sabun cuci tangan yaitu alcohol, emollient, triclocarban, triclosan, triclocarban, dan lainnya. ${ }^{5,17}$

\subsection{Hand-sanitizer}

Hand-saitizer yaitu sebuah produk berbentuk gel yang memiliki kandungan antiseptik sebagi pembersih tangan yang jika menggunakannya tidak perlu dibilas dengan air. ${ }^{8}$ Menggunkannya sangat efektif mematikan flora transien dan residen dibandingkan dengan menggunakan air, pakai sabun biasa maupun sabun antiseptik. ${ }^{8}$ Berdasarkan food and drug administration (FDA) bahwa hand-sanitizer bisa membunuh kuman dalam waktu kurang dari 30 detik. ${ }^{8,2}$

\subsection{Kandungan}

Hand-sanitizer memiliki berbagai macam zat yang terkandung. Secara umum mengandung alkohol 60-90\%, benzalikonium chloride, benzethonium chloride, chlorhexidine, gluconatee, chloroxylenolf, clofucarbang, hexachlorophene, hexylresocarcinol, iodine and iodophors, dan triclosan. ${ }^{11}$ tetapi biasanya yang sering digunakan dalam masyarakat atau yang sering dipakai oleh orang - orang adalah yang kandungannya alkohol dan triklosan. Pada produk Hand-sanitizer terdapat beberapa campuran emolien bermanfaat sebagai pelindung dan pelembut kulit misalnya, tetapi yang sering ditemukan adalah yang terkandung alkohol dan triklosan. Hand-sanitizer ini juga bisa menjaga dan mengahaluskan kulit karena terdapat emolien seperti gliserin, glisol propelin, atau sorbitol. ${ }^{8}$ Menurut Center for Disease Control (CDC) hand-sanitizerterbagi menjadi dua yaitu mengandung alkohol dan tidak mengandung alkohol. Hand-sanitizer dengan kandungan alkohol antara 60-90\% memiliki efek anti mikroba yang baik dibandingkan tanpa kandungan alkohol. ${ }^{8,7}$

Hand-sanitizer tidak menghilangkan kotoran atau zat organik, sehingga jika tangan sangat kotor atau terkontaminasi oleh darah atau cairan tubuh, harus terlebih dahulu tangan dicuci dengan air menggunakan sabun. ${ }^{15,14}$ Selain itu, juga bisa berkurangnya emolien yang menumpuk di tangan setelah berulang kali memakai hand-sanitizer, walaupun sudah memakai hand-sanitizer tetapi kita dianjurkan untuk tetap mencuci tangan dengan sabun, selesai memakai hand-sanitizer 5-10 kali. Terakhir, hand-sanitizer yang bahan aktifnya hanya alkohol mempunyai pengaruh residual terbatas dibanding dengan hand-sanitizer yang berisi campuran alkohol dan antiseptik seperti chlorhexidine. ${ }^{11,14}$

Seiring dengan perkembangan zaman, dimana masyarakat sangat sibuk, terutama yang ada diperkotaan maka munculah produk produk yang serba instan dan praktis yang dapat membersihkan tangan tanpa air yaitu hand-sanitizer atau yang dikenal sebagai 
antiseptik.Produk hand sanitizer ini pun juga semakin beragam, baik komposisinya, zat pembawaannya, serta telah dipasarkan produkproduk baru yang digunakan secara meluas di masyarakat. ${ }^{19}$

\section{KESIMPULAN}

Rahasia dari kekuatan sabun yang mengesankan adalah struktur hibridnya. Sabun tersusun dari molekul yang modelnya seperti pin, pada tiap molekul mempunyai kepala hidrofilik yang dapat menyatu dengan air, sedangkan ekor hidrofobik tidak bisa menyatu dengan air, tetapi hanya bisa bergabung dengan minyak dan lemak. Pada saat molekul molekul ini, tersuspensi dalam air maka molekul tersebut akan bergantian mengapung menjadi unit soliter. Molekul ini bisa terhubung dengan molekul lain pada larutan dan membentuk gelembung - gelembung kecil yang dinamakan misel, posisinya kepala arahnya keluar dan ekor terselip didalamnya.

Mekanisme sabun merusak membran virus COVID-19.Beberapa bakteri virus mempunyai membran lipid mirip misel berlapis ganda yang memiliki dua pita ekor hidrofobik yang dijepit diantara dua cincin kepala hidrofilik.Membran tersebut penuh dengan protein penting sehingga virus memiliki kesempatan untuk menginfeksi sel dan melakukan tugas vital yang menyebabkan bakteri tetap hidup, dalam hal ini termasuk patogen yang dibungkus membran lipid yaitu coronavirus atau yang disebut dengan COVID-19.Sabun dapat membuat membran lemak larut, hal ini membuat virus tidak aktif karena virus tidak aktif lagi.Secara singkatnya, paling banyak virus terbentuk dari tiga blok pembangunan utama yaitu asam ribonukleat (RNA), lipid, dan protein. Pada saat sel terinfeksi virus, maka secara otomatis terbentuk banyak blok bangunan yang berkumpul sendiri menjadi virus. Secara kritis, belum ada ikatan kovalen yang kuat bisa menyatukan unit ini, sehingga tidak membutuhkan bahan kimia keras untuk membuat unit - unit tersebut menjadi terpisah. Saat sel terinfeksi mati, semua virus yang baru ini akan melarikan diri dan terus membuat sel lain terinfeksi. ${ }^{16}$

Dari beberapa sel akan berakhir pada saluran udara paru - paru, sehingga pada saat batuk atau bersin, keluar tetesan kecil dari saluran udara yang bisa terbang sampai 10 meter. Penyebab terbesar yang dianggap sebagai pembawa virus corona utama setidaknya dalam jarak 2 meter.Oleh karena itu, mencuci sesuatu yang terkena virus tidak cukup dengan menggunakan air saja, karena air tidak mampu untuk bersaing dengan segala sesuatu yang interaksinya kuat dan menyerupai lem antara kulit dengan virus. ${ }^{2}$

Berbeda dengan sabun yang kandungannya terdapat lemak yang dikenal sebagai amphiphiles, sebagian diantaranya secara struktual menyerupai lipid pada membran virus.Molekul sabun "bersaing" dengan lipid di dalam membran virus.Ini kurang lebih bagaimana sabun juga menghilangkan kotoran normal dari kulit. Sabun tidak melonggarkan "lem" antara virus dan kulit tetapi juga interaksi seperti Velcro yang menyatuhkan protein, lipid, dan RNA dalam virus.Produk berbasis alkohol, yang mencakup hampir semua produk "disinfektan", mengandung larutan alcohol persentase tinggi (biasanya 60-80\% etanol) dan membunuh virus dengan cara yang sama. Tetapi sabun lebih baik karena hanya membutuhkan sedikit air sabun, yang dengan menggosok, menutupi seluruh tangan dengan mudah.

Dengan merendam virus dalam etanol untuk sesaat, dan menyeka atau menggosok gel di tangan tidak menjamin bahwa bisa merendam setiap sudut kulit di tangan dengan cukup efektif. Pernyataan ini telah dibuktikan dalam satu eksperimen pada roti yang dilakukan oleh salah satu sekolah dasar di Amerika Serikat pada Desember 2019. Roti 
dengan dipegang anak yang telah cuci tangan terbukti bebas dari mikroorganisme dibanding dengan menggunakan hand sanitizer., ${ }^{9,13}$

\section{UCAPAN TERIMA KASIH}

Alhamdulillah, Puji dan syukur saya panjatkan kehadirat Allah SWT yang berkat dan rahmatnya saya dapat menyelesaikan penelitian ini. Tak lupa pula kami ucapkan terimakasih kepada semua pihak yang telah membantu dalam proses penelitian ini Kami pula mengucapkan terimakasih kepada keluarga dan teman-teman yang memberikan dukungan dalam proses pembuatan jurnal ini.

\section{DAFTAR PUSTAKA}

[1] Pandemi koronavirus 2019-2020 [Diakses 11 Mei 2020]. Available at :https://id.wikipedia.org/wiki/Pandemi k oronavirus $2019 \% \mathrm{E} 2 \% 80 \% 932020$

[2] Radji, M., Suryadi, H., Ariyanti, D., Uji Efektivitas Antimikroba Beberapa Merek Dagang Pembersih Tangan Antiseptik, Majalah Ilmu Kefarmasian, 4(1), 1-6, Departemen Farmasi FMIPA-UI, Depok. 2007.

[3] Teare L, 1999. Hand Washing. British Medical Journal, 318 : 686

[4] Trampuz, Andrej and Widmer AF, 2004. Hand Hygiene : A Frequently Missed Livesaving

[5] Health Canada. Second Report on Human Biomonitoring of Environmental Chemicals in Canada. 2013. Retrieved May 20, 2014.http://www.hcsc.gc.ca/ewhsemt/pubs/contaminants/chmsecmscycle2/index-eng.php

[6] Rolf U. Halden, 2014. On the Need and Speed of Regulating Triclosan and Triclocarban in the United States.
Environ.Sci.Technol., 48, 3603-3611. American Chemical Society. Retrieved May 20, 2014.

[7] Al-zahrani SHM, Baghdadi AM. 2012. Evaluation of the efficiency of Non alcoholic-Hand Gel Sanitizers products as an antibacterial. Nature and Science. 10(6): 15-20.

[8] Departemen Kesehatan Republik Indonesia. 2008. Pedoman Pencegahan dan Pengendalian Infeksi di Rumah Sakit dan Fasilitas Pelayanan Kesehatan Lainnya. Jakarta: Departemen Kesehatan Republik Indonesia.

[9] The science of soap - here's how it kills the coronavirus. Available at : https://www.theguardian.com/commentis free $/ 2020 / \mathrm{mar} / 12 /$ science-soap-killscoronavirus-alcohol-based-disinfectants

[10] Radji M, Suryadi H, Ariyanti D. 2007. Uji Efektivitas Antimikroba Beberapa Merek Dagang Pembersih Tangan Antiseptik. Majalah Ilmu Kefarmasian.

[11] Ramadhan I. 2013. Efek Antiseptik Berbagai Merk Hand Sanitizer Terhadap Bakteri Staphylococcus aureus [skripsi]. Jakarta: Universitas Islam Negeri Syarif Hidayatullah.

[12] Saifuddin A, Yayasan Bina Pustaka Sarwono Prawirohardjo. 2006. Buku Acuan Nasional Pelayanan Kesehatan Maternal dan Neonatal. Edisi Keempat. Jakarta: Yayasan Bina Pustaka Sarwono Prawirohardjo.

[13] Why Soap Works. https://www.nytimes.com/2020/03/13/he alth/soap-coronavirus-handwashinggerms.amp.html

[14] Todd E, Michaels BS, Holah J, Smith D, Greig JD, Bartleson CA. 2010. Alcoholbased Antiseptics for Hand 
Vol. 2, No 2 (2020) : Juli

Disinfection and A Comparison of Their Effectiveness with Soaps. J Food Prot 11(73): 2128-40.

[15] Pickering A, Davis J, Boehm A. 2011. Efficacy of Alcohol-based Hand Sanitizer on Hands Soiled with Dirt and Cooking Oil. J Water Health. 3(9): 429533.

[16] Mutiara Patricia Ladimo, Irwan Irwan MERS-CoV (Middle East Respiratory Syndrome-Corona Virus) menggegerkan dunia timur. Journal Health and Sciens : Gorontalo Journal Health \& Sciens Community, Vol. 4 No.1 2020.

DOI : 10.35971/gojhes.v4.1.4666

(17) Irwan, Melinda Akuba

Uji Efektifitas Kombinasi Perasan Jeruk Nipis Dan Mentimun Terhadap Mortalitas Kecoa (2019) Jambura Journal Ofg Health Science And Research, Volume 1 Nomor 2 Tahun 2019.

DOI:Https://Doi.Org/10.35971/Jjhsr.V 1 i2.1879

\{18\}.Irwan, 2018, The model of Risk Behavior at the rise of HIV and AIDS in Adolescent in Gorontalo Province. International Journal of Pharmacy \& Pharmaceutical Research Volume 9 issue 3 June 2017 ISSN : 2349-7203.

http://iippr.humanjournals.com/2017 106/

\{19\} Lintje Boekosoe (2018). Perilaku Hidup Bersih Dan Sehat Pada Tatanan Rumah Tangga Ditinjau Dari Aspek Pengetahuan Dan Status Ekonomi Masyarakat. Journal Health and Sciens : Gorontalo Journal Health \& Sciens Community, Vol. 2 No.2. 2018.

DOI 